\title{
Glutamate (mGluR-5) gene expression in brain regions of streptozotocin induced diabetic rats as a function of age: role in regulation of calcium release from the pancreatic islets in vitro Savitha Balakrishnan, Peeyush Kumar T and CS Paulose*
}

Address: Molecular Neurobiology and Cell Biology Unit, Centre for Neuroscience, Department of Biotechnology, Cochin University of Science and Technology, Cochin-682 022, Kerala, India

Email: Savitha Balakrishnan - biomncb@cusat.ac.in; Peeyush Kumar T - biomncb@cusat.ac.in; CS Paulose* - biomncb@cusat.ac.in

* Corresponding author

Published: 10 November 2009

Journal of Biomedical Science 2009, 16:99 doi:10.1186/1423-0127-16-99

This article is available from: http://www.jbiomedsci.com/content/16/1/99

(C) 2009 Balakrishnan et al; licensee BioMed Central Ltd.

This is an Open Access article distributed under the terms of the Creative Commons Attribution License (http://creativecommons.org/licenses/by/2.0), which permits unrestricted use, distribution, and reproduction in any medium, provided the original work is properly cited.
Received: 19 April 2009

Accepted: 10 November 2009

\begin{abstract}
Metabotrophic glutamate receptors (mGluRs) modulate cellular activities involved in the processes of differentiation and degeneration. In this study, we have analysed the expression pattern of groupI metabotropic glutamate receptor (mGlu-5) in cerebral cortex, corpus striatum, brainstem and hippocampus of streptozotocin induced and insulin treated diabetic rats $(D+I)$ as a function of age. Also, the functional role of glutamate receptors in intra cellular calcium release from the pancreatic islets was studied in vitro. The gene expression studies showed that mGlu-5 mRNA in the cerebral cortex increased siginficantly in 7 weeks old diabetic rats whereas decreased expression was observed in brainstem, corpus striatum and hippocampus when compared to control. 90 weeks old diabetic rats showed decreased expression in cerebral cortex, corpus striatum and hippocampus whereas in brainstem the expression increased significantly compared to their respective controls. In 7 weeks old D+I group, mGlu-5 mRNA expression was significantly decreased in cerebral cortex and corpus striatum whereas the expression increased significantly in brainstem and hippocampus. 90 weeks old $D+1$ group showed an increased expression in cerebral cortex, while it was decreased significantly in corpus striatum, brainstem and hippocampus compared to their respective controls. In vitro studies showed that glutamate at lower concentration $\left(10^{-7} \mathrm{M}\right)$ stimulated calcium release from the pancreatic islets. Our results suggest that mGlu- 5 receptors have differential expression in brain regions of diabetes and $\mathrm{D}+\mathrm{I}$ groups as a function of age. This will have clinical significance in management of degeneration in brain function and memory enhancement through glutamate receptors. Also, the regulatory role of glutamate receptors in calcium release has immense therapeutic application in insulin secretion and function.
\end{abstract}

\section{Introduction}

Glutamate is the major excitatory neurotransmitter in the central nervous system and exerts its action through ionotropic (iGluRs) and metabotropic receptors (mGluRs). mGluRs interact with iGluRs, ion channels and membrane enzymes that modulates cellular activities involved in the processes of differentiation and degeneration [1]. mGluRs have been divided into three subclasses according to the second-messenger pathways activated and their pharmacologic properties [2,3]. mGluR1 receptors are involved in the processing of somatosensory information as they are expressed in the thalamic neurons that receive 
direct sensory input [4]. Activation of group I receptors (mGluR1 and -5) results in an increase in intracellular calcium through a phospholipase C-inositoltriphosphate pathway [5] and inhibits potassium currents. The factors that modulate or disrupt IP3-mediated $\mathrm{Ca}^{2+}$ signaling exert functional regulatory role in age related and other neurodegenerative disorders [6-8].

Diabetes mellitus is an endocrine disorder of carbohydrate metabolism resulting primarily from inadequate insulin release (Type I insulin-dependent diabetes mellitus) or insulin insensitivity coupled with inadequate compensatory insulin release (Type II non-insulin-dependent diabetes mellitus). Diabetes is associated with peripheral as well as central nervous system neuropathy $[9,10]$. Age related changes in the capacity of $\beta$-cell for proliferation affect the insulin production and contribute to a decrease in glucose tolerance with advance in age [11]. The excitatory amino acids, glutamate are pivotal elements in the hypothalamic circuitry involved in the control of pituitary function. Our previous studies reported an enhanced glutamate dehydrogenase activity during diabetes [12,13] and its regulation on brain glutamate toxicity [14]. Recent evidence suggests that metabotropic glutamate receptors are involved in the regulation of hormone secretion in the endocrine pancreas. The endogenous activation of groupI metabotropic glutamate receptors (mGlu5) are reported to be important for an optimal insulin response to glucose [15]. The functional and biochemical studies show that long-term exposure to hyperglycaemia in STZ-induced diabetic rats is associated with glutamate receptor abnormalities $[16,17]$. Increased glutamate content is reported to cause neuronal degeneration [18-20]. Glutamate which causes excitotoxic neuronal damage, increases calcium influx through $\mathrm{N}$-methyl-D-aspartate receptors in post synaptic neurons, leading to phospholipase $\mathrm{A}_{2}$ mediated arachidonic acid release and neuronal injury by inhibiting the sodium ion channels [21]. mGluRs modulate several G-protein-related signal transduction pathways including intracellular calcium $\left(\mathrm{iCa}^{2+}\right)$ that control neuronal development [22]. The synaptic activation of presynaptic Group I mGluRs increase intracellular $\mathrm{Ca}^{2+}$ and an enhancement of spontaneous transmitter release [23]. Also, the role of group I and II (mGluRs) in mediating $\mathrm{Ca}^{2+}$ oscillations was reported in astrocytes in situ [24]. In the present study, we have investigated the gene expression of group I glutamate receptors (mGluR-5), in different brain regions of streptozotocin induced diabetic rats as a function of age. Also, the functional role of glutamate receptors in intracellular calcium release from pancreatic islets was studied in vitro.

Glutamate is essential for synaptic communication in the CNS, but inadequate regulation of extracellular glutamate and glutamate receptor agonists can cause toxicity in the nervous system [25-27] leading to neurodegenerative disorders. Acute or chronic diabetes leads to neurological dysfunction and injury. Group I mGluRs are positively coupled to phosphoinositide hydrolysis and the mobilization of intracellular Calcium leading to excitotoxic cell death. Metabotropic glutamate (mGlu) regulates synaptic glutamate release both in vitro [28] rat brain slices [29] and in vivo [30]. The role of mGluR5 receptors in diabetes brain damage is not reported before. Our present studies on mGluR5 receptor gene expressions will definitely enlighten the involvement of glutamate in diabetes.

\section{Materials and methods Animals}

Wistar weanling rats of 7-9 weeks old and 90-100 weeks old purchased from Amrita Institute of Medical Sciences, Cochin and Kerala Agricultural University, Mannuthy were used for all experiments. They were housed in separate cages under 12 hours light and 12 hours dark periods and were maintained on standard food pellets and water ad libitum. All animal care and procedures were in accordance with the CPCSEA and National Institute of Health guidelines.

\section{Diabetes Induction}

Animals were divided into the following groups as i) Control ii) Diabetic iii) Insulin treated diabetics (D+I) of 7 weeks old and 90 weeks old rats. Each group consisted of 4-6 animals. Diabetes was induced by a single intrafemoral dose [50-60 mg/kg body weight) of streptozotocin (Sigma chemicals Co., St. Louis, MO, U.S.A.) freshly prepared in citrate buffer, pH 4.5 under anesthesia [31-33]. The control rats were given the citrate buffer injection. The insulin treated diabetic group received a daily dose (1 Unit/kg body weight) of Lente and Plain insulin (Abbott India). The dose was increased daily according to the blood glucose level [34]. Blood glucose was estimated by glucose-oxidase peroxidase method using Glucose estimation kit (Merck).

\section{Sacrifice and tissue preparation}

The animals were then sacrificed on $15^{\text {th }}$ day by decapitation. The brain regions were dissected out quickly over ice according to the procedure of Glowinski and Iversen, [35]. The tissues were stored at $-70^{\circ} \mathrm{C}$ until assay.

\section{Analysis of gene expression by Real-Time PCR}

Total RNA was isolated from the brain regions of control and experimental rats using Tri reagent. RNA was reverse transcribed using ABI PRISM cDNA Archive kit. $20 \mu \mathrm{l}$ of the reaction mixture contained $0.2 \mu \mathrm{g}$ total RNA, $10 \times \mathrm{RT}$ buffer, $25 \times$ dNTP mixture, $10 \times$ Random primers, MultiScribe RT ( $50 \mathrm{U} / \mu \mathrm{l})$ and RNase free water. The reactions were carried out at $25^{\circ} \mathrm{C}$ for 10 minutes and $37^{\circ} \mathrm{C}$ for 2 hours using an Eppendorf Personal Cycler. Real-Time PCR 
assays were performed using specific primer and fluorescently labeled Taq probe in an ABI 7300 Real-Time PCR instrument (Applied Biosystems). The TaqMan reaction mixture of $20 \mu$ l contained $25 \mathrm{ng}$ of total RNA-derived cDNAs, $200 \mathrm{nM}$ each of the forward primer, reverse primer and TaqMan probe for mGlu-5 gene, endogenous control, $\beta$-actin and $12.5 \mu \mathrm{l}$ of TaqMan $2 \times$ Universal PCR Mastermix. The thermocycling profile conditions used were: $50^{\circ} \mathrm{C}$ - 2 minutes - Activation; $95^{\circ} \mathrm{C}$ - 10 minutes Initial Denaturation; followed by 40 cycles of $95^{\circ} \mathrm{C}-15$ seconds - Denaturation and $60^{\circ} \mathrm{C}-1$ minute - Annealing. The $\Delta \Delta \mathrm{CT}$ method of relative quantification was used to determine the fold change in expression. This was done by first normalizing the resulting threshold cycle (CT) values of the target mRNAs to the CT values of the internal control $\beta$-actin in the same samples $\left(\Delta \mathrm{CT}=\mathrm{CT}_{\text {Target }}-\mathrm{CT}_{\beta \text {-actin }}\right)$. It was further normalized with the control $(\Delta \Delta \mathrm{CT}=\Delta \mathrm{CT}$ $\left.\mathrm{CT}_{\text {Control }}\right)$. The fold change in expression was then obtained as $\left(2^{-\Delta \Delta C T}\right)$ and expressed as $\log 2^{-\Delta \Delta C T}$.

\section{Primer Sequence}

Beta actin: TCA CCC ACA CTG TGC CCC ATC TAC GA

\section{mGlu-5 receptor: TTCTGGGCAGTGATGGCTGGGCCGA}

\section{Isolation of pancreatic islets}

Pancreatic islets were isolated from 20 weeks old adult Wistar rats by standard collagenase digestion procedures using aseptic techniques [36]. The islets were isolated in HEPES-buffered sodium free Hanks Balanced Salt Solution (HBSS) [37] with the following composition: 137 mM Choline chloride, $5.4 \mathrm{mM} \mathrm{KCl}, 1.8 \mathrm{mM} \mathrm{CaCl}_{2}, 0.8$ $\mathrm{mM} \mathrm{MgSO}_{4}, 1 \mathrm{mM} \mathrm{KH}_{2} \mathrm{PO}_{4}, 14.3 \mathrm{mM} \mathrm{KHCO}_{3}$ and $10 \mathrm{mM}$ HEPES. Autoclaved triple distilled water was used in the preparation of the buffer. The pancreas from both young and old rats was aseptically dissected out into a sterile petridish containing ice cold HBSS and excess fat and blood vessels were removed. The pancreas was cut into small pieces and transferred to a sterile glass vial containing $2 \mathrm{ml}$ collagenase type XI solution $(1.5 \mathrm{mg} / \mathrm{ml}$ in HBSS, $\mathrm{pH}$ 7.4). The collagenase digestion was carried out for 15 minutes at $37^{\circ} \mathrm{C}$ in an environmental shaker with vigorous shaking (300 rpm/minute). The tissue digest was filtered through $500 \mu \mathrm{m}$ nylon screen and the filtrate was washed with three successive centrifugations and resuspensions in cold HBSS. The pancreatic islet preparation having a viability of $>90 \%$ as assessed by Trypan Blue exclusion which was chosen for cell culture and other experiments.

\section{Calcium imaging}

Pancreatic islets were prepared from 20 weeks old adult Wistar rats by collagenase digestion method as mentioned earlier. The isolated islets were incubated for 4 hours at room temperature in $1 \mathrm{ml}$ of RPMI medium containing 5 $\mu \mathrm{M}$ of $\mathrm{Ca}^{2+}$ fluorescent dye, fluo 4-AM (Molecular Probes, Eugene, OR), to monitor the changes in the intracellular $\mathrm{Ca}^{2+}$. After incubation cells were washed twice in indicator free RPMI medium to remove excess dye that was nonspecifically associated with the cell surface, and then incubated for further 30 minutes to allow complete de esterification of intra cellular AM esters. The $35 \mathrm{~mm}$ plates, containing pancreatic islet cells were placed on the stage of a Leica TCS SP5 laser scanning confocal microscope equipped with a HC PL FLUOTAR $20.0 \times 0.50$ dry objective (NA 0.5). Fluo 4-AM was excited with $514 \mathrm{~nm}$ laser lines from an argon laser, with laser intensity set at 38\% of available power. For visualization of Fluo 4-AM, the emission window was set at $508.4 \mathrm{~nm}-571.5 \mathrm{~nm}$. The images were continuously acquired before and after addition of both higher $\left(10^{-4} \mathrm{M}\right)$ and lower concentration (10${ }^{7} \mathrm{M}$ ) of glutamate, at time intervals of 1.318 seconds, for a total of 600 seconds. Time series experiments were performed collecting $512 \times 512$ pixel images at $400 \mathrm{~Hz}$. Fluorescence intensity was analysed using the quantitation mode in LAS-AF software from Leica Microsystems, Germany. A region of interest (ROI) was drawn within a field of view. For each ROI, the pixel intensity was calculated for each image in the 600 seconds sequence to analyse the intracellular $\mathrm{Ca}^{2+}$ release from the pancreatic islet cells in experimental conditions.

\section{Statistics}

Statistical evaluations were performed by Student's t-Test and ANOVA by using Graphpad InStat (Ver.2.04a, San Diego, USA) computer program. Relative Quantification Software was used for analyzing Real-Time PCR results.

\section{Results}

The body weight was significantly decreased ( $\mathrm{p}<0.001$ ) in 7 weeks old and 90 weeks old diabetic rat groups when compared to their respective controls. After insulin treatment for 14 days, the body weight was reversed to near the initial level in both groups (Table 1, 2). Blood glucose level of all rats before streptozotocin administration was within the normal range. Streptozotocin administration led to a significant increase $(\mathrm{p}<0.001)$ in blood glucose level of 7 weeks old and 90 weeks old diabetic rat groups when compared to their respective controls. In both groups, insulin treatment significantly reduce $(\mathrm{p}<0.001)$ the increased blood glucose level to near the control value when compared to diabetic group (Table 3,4).

The gene expression studies using Real-Time PCR showed that the glutamate receptor (mGlu-5) mRNA in the cerebral cortex was increased siginficantly $(\mathrm{p}<0.001)$ in 7 weeks old diabetic rats whereas decreased expression $(\mathrm{p}<$ 0.001 ) was observed in D+I group compared to control. 90 weeks old diabetic rats showed decreased expression ( $\mathrm{p}$ $<0.001$ ) while D+I group showed an increased expression 
Table I: Body weight (g) of Experimental rats (7 weeks old)

\begin{tabular}{llll}
\hline Animal status & Initial & $7^{\text {th }}$ day & 14th day \\
\hline Control & $110.0 \pm 10.0$ & $120.5 \pm 12.0$ & $133.3 \pm 14.5$ \\
Diabetic & $120.0 \pm 5.7$ & $86.6 \pm 4.6$ & $75.7 \pm 3.6^{* * * *} \varphi \varphi \varphi$ \\
Insulin treated Diabetic & $116.6 \pm 3.4$ & $98.2 \pm 2.0$ & $106.6 \pm 5.3$ Tाभा \\
\hline
\end{tabular}

Values are mean \pm S.E.M of 4-6 rats in each group.

$*_{* * *} p<0.001$ when compared with control, $\varphi \varphi \varphi p<0.001$ when compared with initial weight, ${ }^{\pi T T} p<0.001$ when compared with diabetic group.

( $\mathrm{p}<0.001)$ compared to control. Also, the expression was decreased significantly in 90 weeks old diabetic rats $(\mathrm{p}<$ $0.001)$ whereas an increased expression pattern ( $\mathrm{p}<$ 0.001 ) was observed in $\mathrm{D}+\mathrm{I}$ groups compared to 7 weeks old diabetic and $\mathrm{D}+\mathrm{I}$ groups respectively (Fig 1).

In the corpus striatum, the gene expression decreased significantly $(\mathrm{p}<0.001)$ in 7 weeks and 90 weeks old diabetic and D+I groups when compared to control. In 90 weeks old diabetic group, we observed a decreased expression $(\mathrm{p}<0.001)$ whereas $\mathrm{D}+\mathrm{I}$ group showed an increased expression $(\mathrm{p}<0.001)$ compared to 7 weeks old diabetic and $\mathrm{D}+\mathrm{I}$ groups respectively (Fig 2 ). In the brainstem, mGlu-5 mRNA expression was significantly decreased ( $p$ $<0.001)$ in 7 weeks old diabetic whereas it was significantly increased $(\mathrm{p}<0.001)$ in $\mathrm{D}+\mathrm{I}$ groups compared to control. 90 weeks old diabetic rats showed an increased expression while D+I group showed a decreased expression $(\mathrm{p}<0.001)$ compared to control. Also, an increased expression of mGlu-5 receptor mRNA was observed in 90 weeks old diabetic $(p<0.001)$ whereas $D+I$ groups showed decreased expression $(\mathrm{p}<0.001)$ compared to 7 weeks old diabetic and D+I groups respectively (Fig 3).

The hippocampus elicit an increased mGlu-5 receptor mRNA expression $(\mathrm{p}<0.001)$ in 7 weeks old $\mathrm{D}+\mathrm{I}$ groups whereas it was significantly decreased $(p<0.001)$ in 7 weeks diabetic and 90 weeks old rat groups compared to their respective controls. Also, a significant decrease in the expression was observed in 90 weeks old diabetic $(\mathrm{p}<$ $0.001)$ and $\mathrm{D}+\mathrm{I}(\mathrm{p}<0.001)$ groups compared to 7 weeks old diabetic and D+I groups respectively (Fig 4).

In vitro studies showed that glutamate at $10^{-7} \mathrm{M}$ significantly increased $\mathrm{Ca}^{2+}$ release from the pancreatic islets (Fig $5,6)$.

Table 2: Body weight (g) of Experimental rats ( 90 weeks old)

\section{Discussion}

Glutamate is an excitatory neurotransmitter in the mammalian central nervous system and mediates neurotransmission across most excitatory synapses. Metabotrophic glutamate receptors (mGluRs) are mainly found in pre and postsynaptic neurons in synapses of the hippocampus, cerebellum and the cerebral cortex as well as other parts of the brain and in peripheral tissues. Previous reports suggest the in adult rats mGluR-5 is expressed in many brain regions highest in striatum, hippocampus frontal cortex and relatively low in cerebellum and pons medulla $[38,39]$. mGluR-5 receptors expression is precisely and complexly controlled at the level of transcription and that different functions of mGlu5 during different developmental periods and in distinct regions are likely mediated by different splice variants [40].

The progression of diabetes is associated with an impaired ability of the neurons in the CNS to release neurotransmitters resulting in behavioral changes [41]. Among them, the neurotransmitter receptor NMDA showed agerelated reduction of expression [42]. The cerebral cortex is the seat of our highest forms of intelligence. It plays a central role in many complex brain functions including memory, attention, perceptual awareness, thought, language, and consciousness. Glutamate triggers neuronal death when released in excessive concentrations by overexcitation of its receptors [43]. Age-related neuronal dysfunction causes a decline in cognitive function and other subtle changes within the cortex including alterations in receptors, loss of dendrites, and spines and myelin dystrophy, as well as the alterations in synaptic transmission [44]. Glutamate receptor subtypes are critical in gating the plasticity and memory formation. Also, learning and memory deficits are associated with Type I and Type II diabetes mellitus [45] and brain morphological abnormali-

\begin{tabular}{llll}
\hline Animal status & Initial & 1th day & I 4th day \\
\hline Control & $320.0 \pm 12.0$ & $325.0 \pm 14.3$ & $330.0 \pm 15.0$ \\
Diabetic & $360.0 \pm 16.5$ & $280.2 \pm 3.3$ & $250.7 \pm 2.3^{* * * * \varphi \varphi}$ \\
Insulin treated Diabetic & $350.0 \pm 13.3$ & $300.6 \pm 5.0$ & $310.0 \pm 5.8$ Tीभा
\end{tabular}

Values are mean \pm S.E.M of 4-6 rats in each group.

$*_{* *} *_{p}<0.001$ when compared with control, ${ }^{\varphi \varphi} \varphi_{p}<0.00$ I when compared with initial weight, $\|_{1 \uparrow}<0.00$ I when compared with diabetic group. 
Table 3: Blood glucose (mg/dL) level in Experimental rats (7 weeks old)

\begin{tabular}{llllll}
\hline Animal status & $\begin{array}{l}\text { 0 day } \\
\text { (Before STZ injection) }\end{array}$ & $3^{\text {rd }}$ day (Initial) & 6 $^{\text {th }}$ day & 10th day $^{\text {th }}$ & I4th day (Final) \\
\hline Control & $108.6 \pm 1.7$ & $113.1 \pm 0.8$ & $120.5 \pm 1.5$ & $123.7 \pm 0.7$ & $127.5 \pm 0.9$ \\
Diabetic & $105.9 \pm 0.7$ & $256.2 \pm 0.4$ & $301.2 \pm 0.5$ & $305.7 \pm 0.7$ & $306.9 \pm 1.3^{* * * *}$ \\
D + I & $113.5 \pm 1.2$ & $258.8 \pm 0.3$ & $298.4 \pm 0.9$ & $182.8 \pm 1.3$ & $130.0 \pm 1.1$ Tाभा $\varphi \varphi \varphi$ \\
\hline
\end{tabular}

Values are mean \pm S.E.M of 4-6 rats in each group.

*** $P<0.001$ when compared to control, ITाTP $<0.001$ when compared to diabetic group,

$\varphi \varphi \varphi p<0.001$ when compared with initial reading.

$D+$ I- Insulin treated Diabetic

ties have been found in diabetic patients, mainly in the cortex area [46]. Studies on streptozotocin (STZ)-induced diabetic rat models have shown similar results which exhibits morphological, behavioural and electrophysiological alterations on diabetes [47-49]. Increased blood glucose and decreased body weight observed during diabetes is similar with previous reports as a result of the marked destruction of insulin secreting pancreatic islet $\beta$ cells by streptozotocin [50]. During diabetes there is a decrease in body weight as a result of altered metabolic function. Insulin treatment normalised the increased blood glucose level and decreased body weight to control values.

Abnormal expression of glutamate receptor is also involved in the development of diabetic neuropathy [51]. The brain regions - cerebral cortex and hippocampus of diabetic rats is suggested to be more vulnerable to glutamate toxicity via NMDA receptor activation. An Agerelated increase in group-I mGlu receptor mRNA levels was found in thalamic nuclei, hippocampal CA3 with parallel increases in mGlu receptor protein expression [52]. Diabetes mellitus induces cognitive impairment and defects of long-term potentiation (LTP) in the hippocampus. From the gene expression studies, it is clear that in cerebral cortex, mGlu-5 mRNA increased siginficantly in 7 weeks old diabetic rats compared to control groups. Aging process affects NMDA receptors more in the intermediate hippocampus than the dorsal [53]. The dysfunction in hippocampal LTP, an electrophysiological model of synaptic plasticity thought to subserve learning and memory processes is associated with diabetic conditions [54,55]. Also, L- [(3)H]glutamate-labeled NMDA receptors were found to be down regulated in primary sensory cortical regions [56]. Brain stem is an important part of the brain in monitoring the glucose status and the regulation of feeding [57]. The dorsal motor nucleus of the vagus nerve is located in the brainstem. It is connected to the endocrine pancreas exclusively via vagal fibres and has a role in neurally mediated insulin release. Hippocampus is based on recent or declarative memory and plays important roles in long-term memory and spatial navigation. In brainstem, corpus striatum and hippocampus, we observed a decreased expression of mGlu- 5 mRNA when compared to control groups. 90 weeks old diabetic rats showed decreased expression in cerebral cortex, corpus striatum and hippocampus whereas in the brainstem the expression increased significantly. Corpus striatum is best known for its role in the planning and modulation movement pathways but also involved in a variety of cognitive process involving executive function. Studies show an agedependent reduction in the functional response of striatal group I mGlu receptors, which may be one of the factors underlying the reduced ability of aged striatum to integrate information [58]. Our results suggest that glutamate receptor alterations found in the brain regions contribute to cognitive and memory deficits during diabetes as a function of age.

Studies have shown that regulation of glutamate receptor properties can contribute to learning and memory [59]. Activation of this neurotransmitter system is also involved

Table 4: Blood glucose (mg/dL) level in Experimental rats (90 weeks old)

\begin{tabular}{|c|c|c|c|c|c|}
\hline Animal status & $\begin{array}{l}0 \text { day } \\
\text { (Before STZ injection) }\end{array}$ & $3^{\text {rd day (Initial) }}$ & $6^{\text {th }}$ day & I0th day & I4th day (Final) \\
\hline Control & $110.1 \pm 1.5$ & $120.2 \pm 1.7$ & $122.5 \pm 0.6$ & $127.9 \pm 2.1$ & $128.3 \pm 1.21$ \\
\hline Diabetic & $115.7 \pm 1.2$ & $248.9 \pm 1.5$ & $260.5 \pm 0.7$ & $265.7 \pm 0.4$ & $267.9 \pm 1.2^{* * * *}$ \\
\hline$D+I$ & $119.2 \pm 0.7$ & $254.8 \pm 0.6$ & $262.4 \pm 0.9$ & $193.8 \pm 1.2$ & $164.6 \pm 0.9$ गाभा $\varphi \varphi \varphi$ \\
\hline
\end{tabular}

Values are mean \pm S.E.M of 4-6 rats in each group.

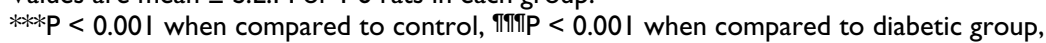

$\varphi \varphi \varphi p<0.001$ when compared with initial reading.

D + I- Insulin treated Diabetic 
Fig-1a (7 weeks old)

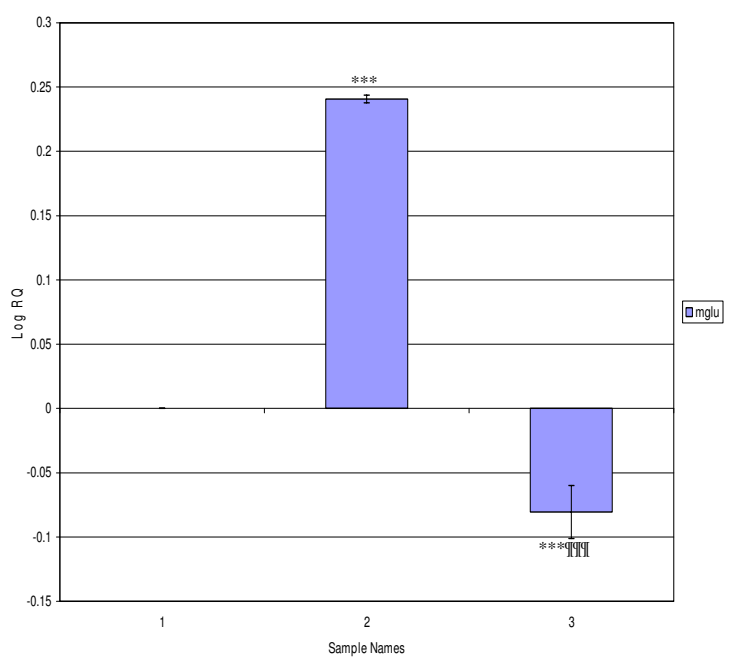

Fig-1b (90 weeks old)

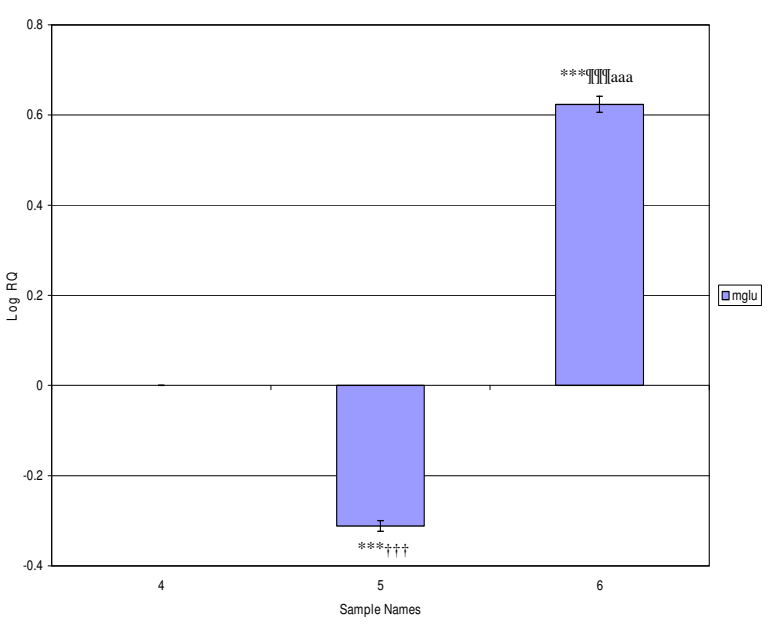

Figure I

Real-Time PCR amplification of Glutamate receptor (mGlu-5) mRNA from the Cerebral cortex of Control, Diabetic and Insulin treated Diabetic Rats. Sample Names. I. 7 weeks Control, 2. 7 weeks Diabetic, 3. 7 weeks Insulin treated Diabetic. 4. 90 weeks Control, 5. 90 weeks Diabetic, 6. 90 weeks Insulin treated Diabetic. Real Time PCR analysis was done using mGlu-5 specific primer and fluorescently labeled Taq probe. The TaqMan reaction mixture of $20 \mu \mathrm{l}$ contained $25 \mathrm{ng}$ of total RNA-derived cDNAs, $200 \mathrm{nM}$ each of the forward primer, reverse primer and TaqMan probe for glutamergic- (mGlu5) gene, endogenous control, $\beta$-actin and $12.5 \mu$ of TaqMan $2 \times$ Universal PCR Mastermix (Applied Biosystems). All reactions were performed in duplicates. The $\triangle \Delta C T$ method of relative quantification was used to determine the fold change in expression. This was done by first normalizing the resulting threshold cycle $(C T)$ values of the target mRNAs to the CT values of the internal control $\beta$-actin in the same samples $\left(\Delta C T=C T_{\text {arget }}-C_{\beta} T_{\beta \text {-actin }}\right)$. It was further normalized with the control $(\Delta \Delta C T=$ $\Delta C T$ - $\left.C T_{\text {Control }}\right)$. The fold change in expression was then obtained as (2- $\left.-\Delta C T\right)$ and expressed as log $2^{-\Delta \Delta C T}$. Values are Mean \pm S.D of 4-6 separate experiments. ***p $<0.00$ I when compared to control, ITाT $p<0.00$ I when compared to diabetic, $+t \dagger p<$ 0.001 when compared to 7 weeks old diabetic, aaa $p<0.001$ when compared to 7 weeks old insulin treated diabetic.

in neurodegeneration following a wide range of neurological insults, including ischemia, trauma and epileptic seizures [60,61]. In rodents, N-methyl-D-aspartate (NMDA) and non-NMDA receptors are two families of ionotropic receptors stimulated by glutamate that have been implicated in neurodegeneration [62]. Overactivation of these receptors can cause cell damage by increasing intracellular calcium concentration in neurons, thereby leading to the generation of free radicals and activation of proteases, phospholipases and endonucleases $[63,64]$ as well as transcriptional activation of specific cell death programs [65].

In 7 weeks old D+I group, mGlu-5 mRNA expression was significantly decreased in cerebral cortex and corpus striatum whereas the expression increased significantly in brainstem and hippocampus. 90 weeks old D+I group showed an increased expression in cerebral cortex, while it was decreased significantly in corpus striatum, brainstem and hippocampus compared to their respective con- trols. Insulin is reported to regulate the reuptake of catecholamine transporters. Intracerebroventricular injection of insulin is reported to cause an increased mRNA expression of dopamine transporters [66]. Short-term insulin treatment was found to alter NMDA receptor activation [67] as well as to interact with AMPA receptor trafficking between the plasma membrane and the intracellular compartment in neuronal cell culture [68] indicating that mechanisms underlying diabetic neuropathies could be initiated in the early stages of the disease, as a consequence of abnormal glutamate receptor properties. This is relevant to the clinical situation because excessive activation of glutamate receptors is a characteristic feature of brain damage during stroke and ischaemia [69], conditions that are exacerbated by hyperglycaemic states.

Intracellular $\mathrm{Ca}^{2+}$ plays a major role in the physiological responses of excitable cells and excessive accumulation of internal $\mathrm{Ca}^{2+}$ is a key determinant of cell injury and death [70]. Pancreatic islet cells express receptors and transport- 
Fig-2a (7 weeks old)

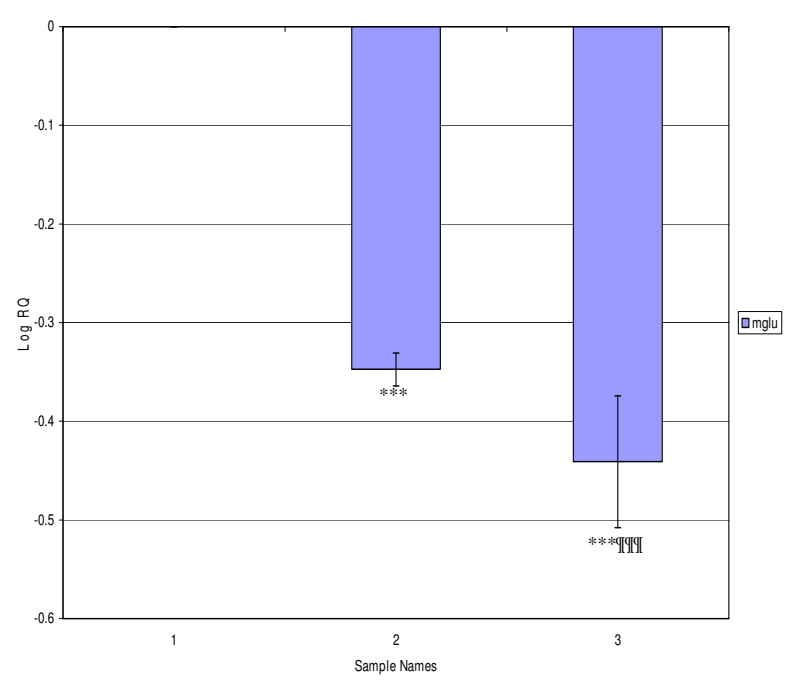

Fig-2b (90 weeks old)

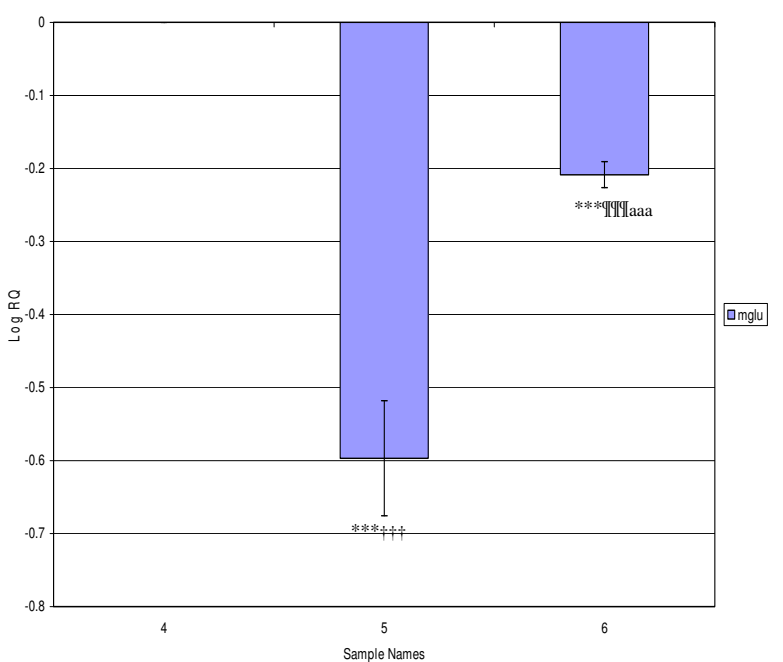

\section{Figure 2}

Real-Time PCR amplification of Glutamate receptor (mGlu-5) mRNA from the Corpus striatum of Control, Diabetic and Insulin treated Diabetic Rats. Sample Names. I. 7 weeks Control, 2. 7 weeks Diabetic, 3.7 weeks Insulin treated Diabetic. 4. 90 weeks Control, 5. 90 weeks Diabetic, 6. 90 weeks Insulin treated Diabetic. Values are Mean \pm S.D of 46 separate experiments. ${ }^{* * *} \mathrm{p}<0.00 \mathrm{I}$ when compared to control, $\mathrm{TT}_{\mathrm{T}} \mathrm{p}<0.00 \mathrm{I}$ when compared to diabetic, $\mathrm{tt \dagger p}<0.00 \mathrm{I}$ when compared to 7 weeks old diabetic, ${ }^{a a a} p<0.001$ when compared to 7 weeks old insulin treated diabetic. Other details as in the legend to Figure-I.

Fig-3a (7 weeks old)

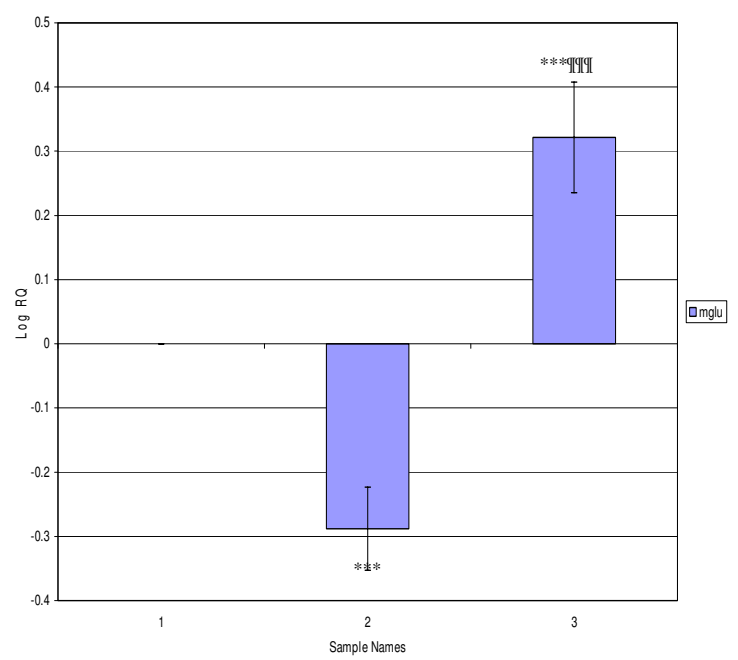

Fig-3b (90 weeks old)

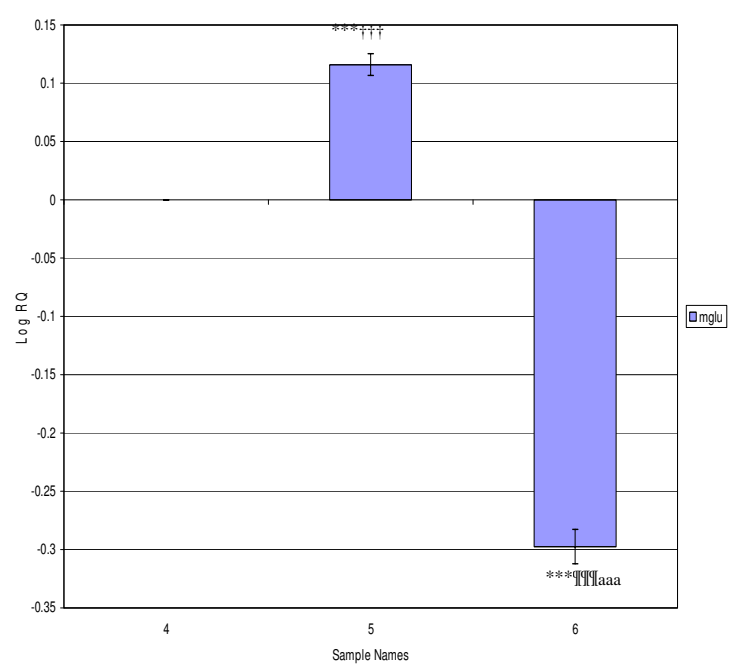

\section{Figure 3}

Real-Time PCR amplification of Glutamate receptor (mGlu-5) mRNA from the Brainstem of Control, Diabetic and Insulin treated Diabetic Rats. Sample Names. I. 7 weeks Control, 2. 7 weeks Diabetic, 3. 7 weeks Insulin treated Diabetic. 4. 90 weeks Control, 5. 90 weeks Diabetic, 6. 90 weeks Insulin treated Diabetic. Values are Mean \pm S.D of 4-

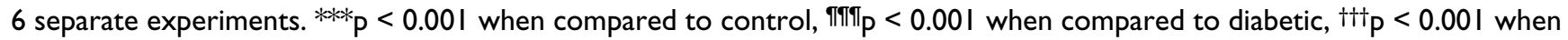
compared to 7 weeks old diabetic, aaa $p<0.001$ when compared to 7 weeks old insulin treated diabetic. Other details as in the legend to Figure-I. 
Fig-4a (7 weeks old)

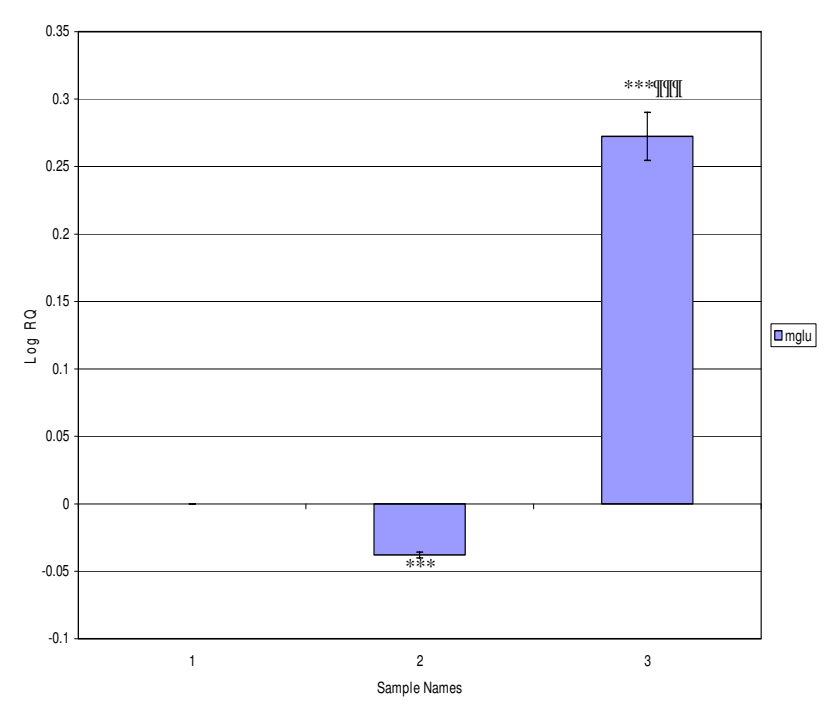

Fig-4b (90 weeks old)

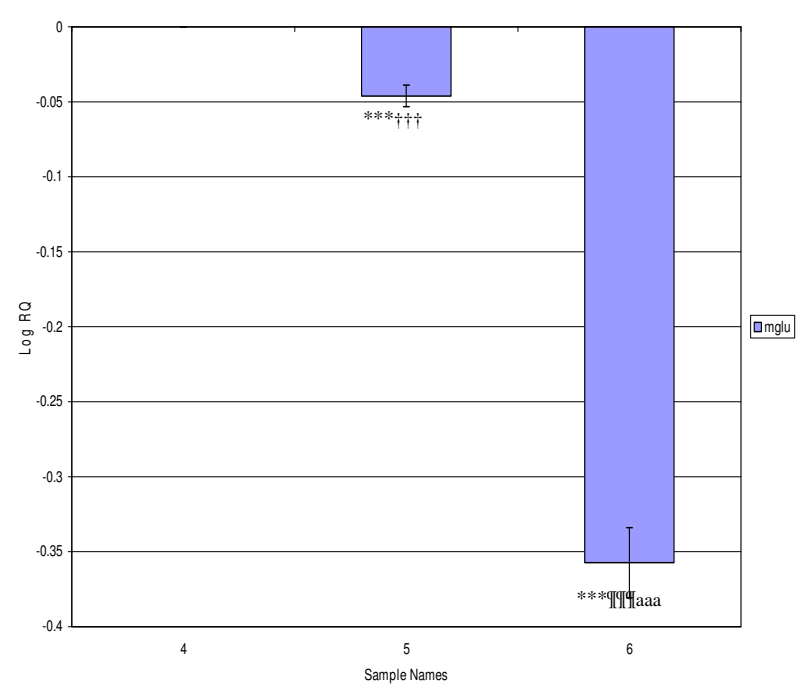

\section{Figure 4}

Real-Time PCR amplification of Glutamate receptor (mGlu-5) mRNA from the Hippocampus of Control, Diabetic and Insulin treated Diabetic Rats. Sample Names. I. 7 weeks Control, 2. 7 weeks Diabetic, 3. 7 weeks Insulin treated Diabetic. 4. 90 weeks Control, 5. 90 weeks Diabetic, 6. 90 weeks Insulin treated Diabetic. Values are Mean \pm S.D of 46 separate experiments. ${ }^{* * *} p<0.00 \mathrm{I}$ when compared to control, $\uparrow \uparrow \uparrow \mathrm{p}<0.00 \mathrm{I}$ when compared to diabetic, $t+\dagger \mathrm{p}<0.00 \mathrm{I}$ when compared to 7 weeks old diabetic, ${ }^{a a a} p<0.001$ when compared to 7 weeks old insulin treated diabetic. Other details as in the legend to Figure-I.

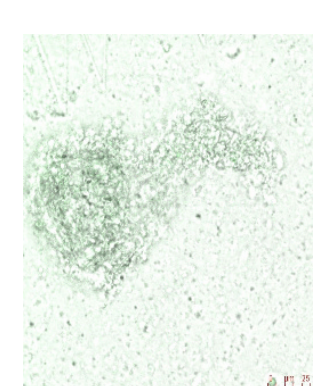

Initial fluorescence

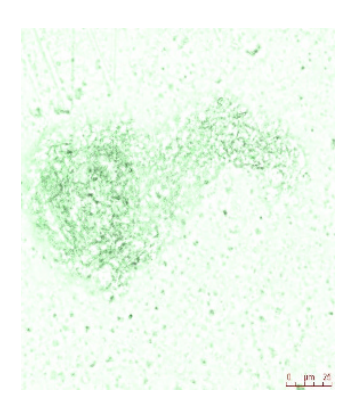

fluor escence after $3 \mathrm{~min}$

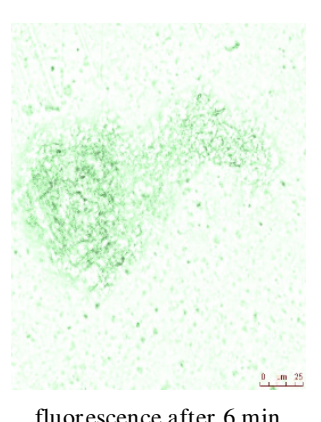

fluorescence after $6 \mathrm{~min}$

\begin{tabular}{|c|c|}
\hline Time in min & Pixel intensity \\
\hline 0 & 702335 \\
\hline 3 & 1859753 \\
\hline 6 & 2110466 \\
\hline
\end{tabular}

\section{Figure 5}

The isolated pancreatic islets were incubated for 4 hours at room temperature in I ml of RPMI medium containing $5 \mu \mathrm{M}$ of $\mathbf{C a}^{2+}$ fluorescent dye, fluo 4-AM. The images were continuously acquired before and after addition of I0$7 \mathrm{M}$ of glutamate, at time intervals of 1.318 seconds, for a total of 600 seconds. Time series experiments were performed collecting $512 \times 512$ pixel images at $400 \mathrm{~Hz}$. Fluorescence intensity was analysed using the quantitation mode in LAS-AF software from Leica Microsystems, Germany. A region of interest (ROI) was drawn within a field of view. The pixel intensity was calculated for each image in the 600 seconds sequence to analyse the intracellular $\mathrm{Ca}^{2+}$ release from the pancreatic islet cells in experimental conditions. 


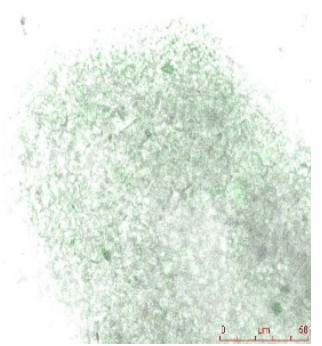

Initial fluorescence

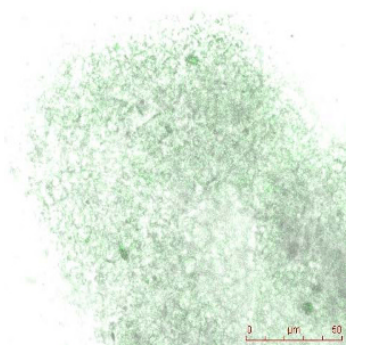

fluorescence after $3 \mathrm{~min}$

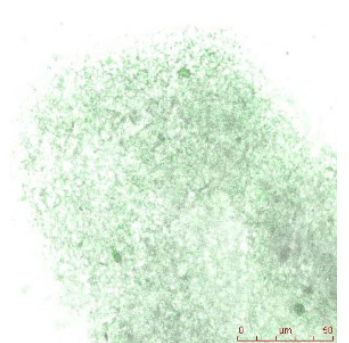

fluor escence after $6 \mathrm{~min}$

\begin{tabular}{|c|c|}
\hline Time in min & Pixel intensity \\
\hline 0 & 408437 \\
\hline 3 & 552820 \\
\hline 6 & 640085 \\
\hline
\end{tabular}

\section{Figure 6}

The isolated pancreatic islets were incubated for 4 hours at room temperature in I ml of RPMI medium containing $5 \mu \mathrm{M}$ of $\mathbf{C a}^{2+}$ fluorescent dye, fluo 4-AM. The images were continuously acquired before and after addition of I0$4 \mathrm{M}$ of glutamate, at time intervals of $\mathrm{I} .318$ seconds, for a total of 600 seconds. Time series experiments were performed collecting $512 \times 512$ pixel images at $400 \mathrm{~Hz}$. Fluorescence intensity was analysed using the quantitation mode in LAS-AF software from Leica Microsystems, Germany. A region of interest (ROI) was drawn within a field of view. The pixel intensity was calculated for each image in the 600 seconds sequence to analyse the intracellular $\mathrm{Ca}^{2+}$ release from the pancreatic islet cells in experimental conditions.

ers for L-glutamate and use L-glutamate as an intercellular signaling molecule [71]. Both $\alpha$ and $\beta$-cells possess functional vesicular glutamate transporters regulated by alteration in glucose concentration via the transcriptional mechanism [72]. Maechler and Wollheim [73] recently provided evidence that glutamate acts downstream of the mitochondria by sensitizing the $\mathrm{Ca}^{2+}$-mediated exocytotic process. Our studies showed that glutamate at lower concentration $\left(10^{-7} \mathrm{M}\right)$ increased $\mathrm{Ca}^{2+}$ release from the pancreatic islet cells of male Wistar rats in vitro. Also, the stimulatory effect of glutamate on $\mathrm{Ca}^{2+}$ release was found to be decreased at higher concentration $\left(10^{-4} \mathrm{M}\right)$. The activation of mGluR increase intracellular calcium through a phospholipase C-inositoltriphosphate pathway [74] and inhibits potassium currents. The resultant cytosolic $\mathrm{Ca}^{2+}$ transients serve numerous signaling functions, including modulation of membrane excitability [75,76], synaptic plasticity $[77,78]$, and gene expression [79]. Glutamate receptors regulate $\mathrm{Ca}^{2+}$-dependent secretory mechanisms in islet cells by altering the membrane potential of these cells. The ability of mGluR to increase intracellular $\mathrm{Ca}^{2+}$ depends on their co-expression with voltage-gated $\mathrm{Ca}^{2+}$ channels and on the ionic gradients present in the cells in which they are expressed [80]. The metabolic changes in islet cells reported an increase in cellular ATP that closes
ATP-sensitive potassium channels causing depolarization of the plasma membrane potential. Subsequently, depolarization opens voltage-sensitive $\mathrm{Ca}^{2+}$ channels, raising intracellular $\mathrm{Ca}^{2+}$ concentration and triggering insulin exocytosis. The factors that modulate or disrupt IP3mediated $\mathrm{Ca}^{2+}$ signaling exert functional regulatory role in physiological and pathological effects in the pancreatic islets [81]. Thus, we conclude from our results that mGlu5 receptors have differential expression in brain regions of diabetes and D+I groups as a function of age. Also, the present study reveals the functional regulatory role of glutamate receptors at different concentrations in intracellular calcium release from pancreatic islets in vitro. In conclusion, the study elicits immense therapeutic applications of glutamate receptors in memory enhancement and management of degeneration in brain function during diabetes and ageing. Also, the functional role of glutamate receptors in calcium release has clinical significance in insulin secretion and function.

\section{Competing interests}

The authors declare that they have no competing interests. 


\section{Authors' contributions}

SB and CSP designed research. SB performed experiments. PKT helped SB in experiments. SB and CSP analyzed the data. SB and CSP wrote the paper. All authors read and approved the final manuscript.

\section{Acknowledgements}

This work was supported by grants from DST, DBT, ICMR, Govt. of India, KSCSTE, Govt. of Kerala, to Dr. C. S. Paulose. B. Savitha thanks Cochin University of Science and Technology for JRF.

\section{References}

I. Alvarez FJ, Dewey DE, Carr PA, Cope TC, Fyffe RE: Downregulation of metabotropic glutamate receptor I a in motoneurons after axotomy. Neuroreport 1997, 8:1711-1716.

2. Pin JP, Duvoisin R: The metabotropic glutamate receptors: structure and functions. Neuropharmacology 1995, 34: I-26.

3. Hollmann M, Heinemann S: Cloned glutamate receptors. Annu Rev Neurosci 1994, 1 7:31-108.

4. Lourenco Neto F, Schadrack J, Berthele A, Zieglgansberger W, Tolle TR, Castro-Lopes JM: Differential distribution of met;abotropic glutamate receptor subtype mRNAs in the thalamus of the rat. Brain Res 2000, 854:93-105.

5. Masu M, Tanabe Y, Tsuchida K, Shigemoto R, Nakanishi S: Sequence and expression of a metabotropic glutamate receptor. Nature 1991, 349:760-765.

6. Abe T, Sugihara $\mathrm{H}, \mathrm{Nawa} \mathrm{H}$ : Molecular characterization of a novel metabotropic glutamate receptor $\mathrm{mGluR5}$ coupled to inositol phosphate/Ca2+ signal transduction. J Biol Chem 1992, 267:|336|-|3368.

7. Mattson MP, LaFerla FM, Chan SL, Leissring MA, Shepel PN, Geiger JD: Calcium signaling in the ER: its role in neuronal plasticity and neurodegenerative disorders. Trends Neurosci 2000, 23:222-229.

8. LaFerla FM: Calcium dyshomeostasis and intracellular signalling in Alzheimer's disease. Nat Rev Neurosci 2002, 3:862-872.

9. Satoshi G, Ynichi H, Morsio K: Altered cardiac adrenergic neurotransmission in streptozotocin-induced diabetic rats. $\mathrm{Br} J$ Pharmacol 1993, 109:1276-1281.

10. Yagihashi S, Sima AAF: Diabetic autonomic neuropathy. The distribution of structural changes in sympathetic nerves of the BB rat. Am J Pathol 1985, I 2 I: I38-147.

II. Hellerstrom C: The life story of the pancreatic B cell. Diabetologia 1984, 26:393-400.

12. Preetha N, Padayatti PS, Abraham A, Sudha B, Raghu KG, Paulose CS: Glutamate dehydrogenase induction in the brain of streptozotocin diabetic rats. Indian J Biochem Biophys 1996, 33:428-430.

13. Aswathy RN, Biju MP, Paulose CS: Effect of pyridoxine and insulin administration on brain glutamate dehydrogenase activity and blood glucose control in streptozotocin-induced diabetic rats. Biochim Biophys Act 1998, I 38 I:35 I-354.

14. Biju MP, Paulose CS: Brain glutamate dehydrogenase changes in streptozotocin-induced diabetic rats as a function of age. Biochem Mol Biol Int 1998, 44:I-7.

15. Storto M, Capobianco L, Battaglia G, Molinaro G, Gradini R, Riozzi B, Di Mambro A, Mitchell KJ, Bruno V, Vairetti MP, Rutter GA, Nicoletti $\mathrm{F}$ : Insulin secretion is controlled by mGlu5 metabotropic glutamate receptors. Mol Pharmacol 2006, 69(4): |234-4|.

16. Gange J, Milot M, Gelinas S: Binding properties of glutamate receptors in streptozotocin-induced diabetes in rats. Diabetes 1997, 46:841-846.

17. Di Luca M, Ruts L, Gardoni F, Cattabeni F, Biessels GJ, Gispen WH: NMDA receptor subunits are modified transcriptionally and post-translationally in the brain of streptozotocin-diabetic rats. Diabetologia 1999, 42:693-70I.

18. Atlante A, Gagliardi S, Minervini GM, Cotti MT, Marray E, Calissano $P$ : Glutamate neurotoxicity in rat cerebellar granule cells: a major role for xanthine oxidase in oxygen radical formation. J Neurochem 1997, 68:2038-2045.

19. Berman FW, Murray TF: Characterization of glutamate toxicity in cultured rat cerebellar granule neurons at reduced temperature. J Biochem Toxicol 1996, I I:I II-I I9.
20. Budd SL, Nicholas DG: Mitochondria, calcium regulation, and acute glutamate excitotoxicity in cultured cerebellar granule cells. J Neurochem 1996, 67:2282-2291.

21. Fraser DD, Hoehn K, Weiss S, Mac Vicar BA: Arachidonic acid inhibits sodium currents and synaptic transmission in cultured striatal neurons. Neuron 1993, I I:633-644.

22. Maiese Kenneth, Ahmad Ishtiaq, TenBroeke Michelle, Jennifer, Gallant : Metabotropic glutamate receptor subtypes independently modulate neuronal intracellular calcium. Journal of Neuroscience Research 1999, 55:4472-4485.

23. Neil E, Alford Schwartz Simon: Physiological activation of presynaptic metabotropic glutamate receptors increases intracellular calcium and glutamate release. J Neurophysiol 2000, 84:4I5-427.

24. Zur Nieden R, Deitmer JW: The role of metabotropic glutamate receptors for the generation of calcium oscillations in rat hippocampal astrocytes in situ. Cereb Cortex 2006, I6(5):676-87.

25. Olney JW: Excitatory amino acids and neuropsychiatric disorders. Biol Psychiatry 1989, 26:505-525.

26. Choi DW: Excitotoxic cell death. J Neurobiol I992, 23: | 26 I-I 276.

27. Doble A: The role of excitotoxicity in neurodegenerative disease: Implications for therapy. Pharmacol Ther 1999, 81: |63-221.

28. Herrero I, Miras-Portugal MT, Sánchez-Prieto J: Rapid desensitization of the metabotropic glutamate receptor facilitates glutamate release in rat cerebrocortical nerve terminals. Eur jNeurosci 1994, 6: II5-120.

29. Croucher MJ, Morant R, Thomas LS, Jane DE: Evidence for a role of group I metabotropic glutamate receptors in the positive feedback control of synaptic glutamate release in vitro. Pharmacologist 1997, 39:2।5.

30. Patel DR, Croucher MJ: Evidence for a role of presynaptic AMPA receptors in the control of neuronal glutamate release in therat brain. Eur J Pharmacol 1997, 332:|43-|5I.

31. Junod A, Lambert AE, Staufferacher W, Renold AE: Diabetogenic action of Streptozotocin: Relationship of dose to metabolic response. J Clin Invest 1969, 48:2129-2I39.

32. Hohenegger $M$, Rudas : Kidney functions in experimental diabetic ketosis. Diabetologia 197I, I 7:334-338.

33. Arison RN, Ciaccio El, Glitzer MS, Cassaro AV, Pruss M: Light and electron microscopy of lesions in rats rendered diabetic with streptozotocin. Diabetes 1967, 16:51-56.

34. Sasaki S, Bunag RD: Insulin reverses hypertension and hypothalamic depression in streptozotocin diabetic rats. Hypertension 1983, L5:34-40.

35. Glowinski J, Iversen LL: Regional studies of catecholamines in the rat brain: the disposition of $[3 \mathrm{H}]$ norepinephrine, $[3 \mathrm{H}]$ dopa in various regions of brain. J Neurochem 1966, 13:655-669.

36. Howell SL, Taylor KW: Potassium ions the secretion of insulin by islets of Langerhans incubated in vitro. Biochem J 1968, I08: 17-24.

37. Pipeleers DG, Veld IPA, DeWinkle VM, Maes E, Schuit FC, Gepts W: $A$ new in vitro model for the study of pancreatic $A$ and $B$ cells. Endocrinology 1985, I I 7:806-816.

38. Nicoletti F, Bruno V, Copani A, Casabona G, Knopfel T: Metabotropic glutamate receptors: a new target for the therapy of neurodegenerative disorders? Trends Neurosci 1996, 19:267-27I.

39. Abe T, Sugihara H, Nawa H, Shigemoto R, Mizuno N, Nakanishi S: Molecular characterization of a novel metabotropic glutamate receptor $\mathrm{mGluR5}$ coupled to inositol phosphate/Ca2+ signal transduction. J Biol Chem 1992, 267:|336|-|3368.

40. Romano C, Smouta S, Millera JK, O'Malley KL: Developmental regulation of metabotropic glutamate receptor $5 \mathrm{~b}$ protein in rodent brain. Neuroscience 2002, I I I:693-698.

41. Broderick PA, Jacoby $\mathrm{JH}$ : Central monoamine dysfunction in diabetes: psychotherapeutic implications: electro analysis by voltammetry. Acta Physiol Pharmacol Latinoam 1989, 39:2 I I-225.

42. Lu T, Pan Y, Kao SY, Li C, Kohane I, Chan J, Yankner BA: Gene regulation and DNA damage in the ageing human brain. Nature 2004, 429:883-89I.

43. Vizi ES: Role of high affinity receptors and membrane transporters in nonsynaptic communication and drug action in the central nervous system. Pharmacol Rev 2000, 52:63-89.

44. Dickstein DL, Kabaso D, Rocher AB, Luebke Jl, Wearne SL, Hof PR: Changes in the structural complexity of the aged brain. Aging Cell 2007, 6:275-84. 
45. Gispen $W H$, Biessels G]: Cognition and synaptic plasticity in diabetes mellitus. Trends Neurosci 2000, 23:542-549.

46. Dejgaard A, Gade A, Larsson H, Balle V, Parving A, Parving HH: Evidence for diabetic encephalopathy. Diabet Med I99I, 8:162-167.

47. Jakobsen J, Sidenius P, Gundersen HJG, Osterby R: Quantitative changes of cerebral neocortical structure in insulin- treated long-term streptozotocin-induced diabetes in rats. Diabetes 1987, 36:597-601.

48. Biessel G], Kamal A, Ramakers GM: Place learning and hippocampal synaptic plasticity in streptozotocin-induced diabetes rats. Diabetes 1996, 45:1259-1267.

49. Chabot C, Massicotte G, Milot M, Trudeau F, Gagne J: Impaired modulation of AMPA receptors by calcium-dependent processes in streptozotocin-induced diabetic rats. Brain Res 1997, 768:249-256.

50. Junod A, Lambert AE, Staufferacher W, Renold AE: Diabetogenic action of Streptozotocin: Relationship of dose to metabolic response. J Clin Invest 1969, 48:21 29-2139.

5I. Tomiyama M, Furusawa K, Kamijo M, Kimura T, Matsunaga M, Baba M: Upregulation of mRNAs coding for AMPA and NMDA receptor subunits and metabotropic glutamate receptors in the dorsal horn of the spinal cord in a rat model of diabetes mellitus. Brain Res Mol Brain Res 2005, 20:2750-278I.

52. Simonyi A, Ngomba RT, Storto M, Catania MV, Miller LA, Youngs B, DiGiorgi-Gerevini $V$, Nicoletti F, Sun GY: Expression of groups I and II metabotrophic glutamate receptors in the rat brain during aging. Brain Res 2005, 043:95-106.

53. Magnusson KR, Kresge $D$, Supon J: Differential effects of aging on NMDA receptors in the intermediate versus the dorsal hippocampus. Neurobiol Aging 2006, 27:324-33.

54. Biessels G], Kamal A, Ramakers GM: Place learning and hippocampal synaptic plasticity in streptozotocin-induced diabetes rats. Diabetes 1996, 45:1259-1267.

55. Di Mario U, Morrano S, Valle E, Pozzessere G: Electrophysiological alteration of the central nervous system in diabetes mellitus. Diabetes Metab Rev 1995, I I:259-277.

56. Bean L, Zheng H, Patel KP, Monaghan DT: Regional variations in NMDA receptor downregulation in streptozotocin-diabetic rat brain. Brain Res 2006, II I 5:217-22.

57. Pénicaud L, Leloup C, Lorsignol A, Alquier T, Guillod E: Brain glucose sensing mechanism and glucose homeostasis. Curr Opin Clin Nutr Metab Care 2002, 5:539-43.

58. Pintor A, Potenza RL, Domenici MR, Tiburzi F, Reggio R, Pezzola A, Popoli P: Age-related decline in the functional response of striatal group I mGlu receptors. Neuroreport 2000, I I:3033-8.

59. Massicotte G: Modification of glutamate receptor by phospholipase A2: its role in adaptive neural plasticity. Cell Mol Life Sci 2000, 57: 1542-1550.

60. Hollmann M, Heinemann S: Cloned glutamate receptors. Annu Rev Neurosci 1994, 17:31-108.

61. Lipton SA, Rosenberg PA: Excitatory amino acids as a final common pathway for neurologic disorders. N Engl J Med 1994, 331:274-275.

62. Dingledine R, Borges K, Bowie D, Traynelis SF: The glutamate receptor ion channels. Pharmacol Rev 1999, 5 I:7-61.

63. Coyle JT, Puttfarcken P: Oxidative stress, glutamate and neurodegenerative disorders. Science 1993, 262:689-695.

64. Siesjo BK, Zhao Q, Phalmark K, Siesjo P, Katsura K, Folbergrova J: Glutamate, calcium, and free radicals as mediators of ischemic brain damage. Ann Thorac Surg 1995, 59:1316-1320.

65. Schreiber SS, Baudry M: Selective neuronal vulnerability in the hippocampus - a role for gene expression? Trends Neurosci 1995, 18:446-451.

66. Figlewicz DP, Patterson TA, Johnson LB, Zavosh A, Israel PA, Szot P: Dopamine transporter mRNA is increased in the CNS of Zucker fatty (fa/fa) rats. Brain Res Bull 1998, 46: 199-202.

67. Liu L, Brown JC, Webster WW, Morrisett RA, Monaghan DT: Insulin potentiates $\mathbf{N}$-methyl-Daspartate receptor activity in Xenopus oocytes and rat hippocampus. Neurosci Lett 1995, 192:5-8.

68. Man HY, Lin JW, Ju WH: Regulation of AMPA-receptor-mediated synaptic transmission by clathrin-dependent receptor internalization. Neuron 2000, 25:649-662.

69. McCall AL: The impact of diabetes on the CNS. Diabetes 1992 , 4I:557-570.
70. Yubo R, Andrew R, Elaine C, Peter KS: Calcium imaging in live rat optic nerve myelinated axons in vitro using confocal laser microscopy. Journal of Neuroscience Methods 2000, 102:165-176.

7I. Yamada H, Otsuka M, Hayashi M, Nakatsuka S, Hamaguchi K, Yamamoto A, Moriyama Y: Ca2+-dependent exocytosis of Lglutamate by alphaTC6, clonal mouse pancreatic alpha-cells. Diabetes 200I, 50(5): I0I2-20.

72. Bai L, Zhang X, Ghishan FK: Characterization of vesicular glutamate transporter in pancreatic alpha - and beta -cells and its regulation by glucose. Am J Physiol Gastrointest Liver Physiol 2003, 284(5):G808-I 4.

73. Maechler $\mathrm{P}$, Wollheim $\mathrm{CB}$ : Mitochondrial glutamate acts as a messenger in gl-induced insulin exocytosis. Nature 1999, 402(6762):595-6.

74. Masu M, Tanabe Y, Tsuchida K, Shigemoto R, Nakanishi S: Sequence and expression of a metabotropic glutamate receptor. Nature 1991, 349:760-765.

75. Yamamoto K, Hashimoto K, Nakano M, Shimohama S, Kato N: A distinct form of calcium release down-regulates membrane excitability in neocortical pyramidal cells. Neuroscience 2002, 109:665-676.

76. Stutzmann GE, LaFerla FM, Parker I: Ca2+ signaling in mouse cortical neurons studied by two-photon imaging and photoreleased inositol triphosphate. J Neurosci 2003, 23:758-765.

77. Fujii S, Matsumoto M, Igarashi K, Kato H, Mikoshiba K: Synaptic plasticity in hippocampal CAI neurons of mice lacking type I inositol-1,4,5-trisphosphate receptors. Learn Mem 2000, 7:312-320.

78. Nishiyama M, Hong K, Mikoshiba K, Poo MM, Kato K: Calcium stores regulate the polarity and input specificity of synaptic modification. Nature 2000, 408:584-588.

79. Mellström B, Naranjo JR: Mechanisms of $\mathrm{Ca}(2+)$-dependent transcription. Curr Opin Neurobiol 200I, I I:3/2-3|9.

80. Weaver CD, Partridge JG, Yao TL, Moates JM, Magnuson MA, Verdoorn TA: Activation of glycine and glutamate receptors increases intracellular calcium in cells derived from the endocrine pancreas. Mol Pharmacol 1998, 54(4):639-46.

8I. Vladimir Parpura, Philip G, Haydon: Physiological astrocytic calcium levels stimulate glutamate release to modulate adjacent neurons. PNAS 2000, 97:8629-8634.

Publish with Bio Med Central and every scientist can read your work free of charge

"BioMed Central will be the most significant development for disseminating the results of biomedical research in our lifetime. "

Sir Paul Nurse, Cancer Research UK

Your research papers will be:

- available free of charge to the entire biomedical community

- peer reviewed and published immediately upon acceptance

- cited in PubMed and archived on PubMed Central

- yours - you keep the copyright 